\title{
Cinema on Trial: Doctrine of Prior Restraint in Censorship
}

Swagat Baruah*

\section{Abstract}

This paper sets to address the legal question of how the Censor Board can exercise such power and whether it represents the mood and approach of the government towards films and art forms in general, in India. What history tells us is quite contrary to what we're witnessing today. Our Constitution makers, while debating on the topic of freedom of speech and expression invoked libertarian philosophers like Isaiah Berlin and John Stuart Mill, and their philosophy did in fact, find its way into the said provision. The present scenario however, is one where we have departed from these libertarian ideas. What the censor board is doing today is trying to choke the marketplace of ideas at its source, which Gautam Bhatia calls 'prior restraint' in his new book Offend, Shock or Disturb. The paper tries to establish how the law of censorship, whenever rigid, has only suppressed thought and dissent, instead of allowing progressive and rational thinking. This is substantiated by analysing various case laws.

Keywords: Censorship, Obscenity test, Moral regulation, Prior restraint, Reasonable restrictions

\section{Introduction}

Censorship and the law in any state reflect the mood of the majority, in some way or the other. The choices made by any

* Gujarat National Law University, Gujarat, India; swagatb13@gmail.com 
regime - democratic or otherwise - come from an electoral confidence, and mandate. An artist, at any given point of time, is reacting to life around him. And is willing to dissent and talk about things that he/she does not like or wants to improve. To that end, it's an ongoing battle with any government that is in power, because dissent is almost always against prevailing control. The most clever and intelligent regimes leave spaces open for dissent because that keeps base urges weak. Whenever control becomes unreasonable, the voices also gather steam and increased resolve. Self-censorship is probably the biggest challenge in moments like these, but the strongest voices are often the most fearless. ${ }^{1}$

In February this year, when the Censor Board, in continuation of its irrational and unreasoned bans, decided to deny the film certification to the film 'Lipstick Under My Burkha' for its "continuous sexual scenes, abusive words, audio pornography"2 and also for it being "lady oriented and about their fantasy about life", the film industry first had to recover from the shock that it inflicted, before proceeding to protest against it. But what makes such an illogical restraint on freedom of speech and expression legally possible, although not justifiable?

\section{Freedom of Speech \& Expression in India}

The Indian Constitution demonstrates through its various provisions, how complex segmented societies may adopt a complex segmented constitution. Our founding fathers understood the need for not only 'national identity' but also 'individual identity' and took up a gradual approach towards achieving it. Out of the many special features that our Constitution carries, one of its most important ones is the policy of accommodation, which to Granville Austin, was one of the original contributions to the process of constitution making. In the Assembly, as Austin argued, the

1 Swagat Baruah, Faces Interview With Kanu Behl, Catharsis Magazine(April 7, 2017), https:/ / catharsismagazine.com/2017/04/07/faces-kanu-behl/.

2 Censor Board refuses to certify Lipstick Under My Burkha, The Hindu (New Delhi)(Feb. 23, 2017, 06:07 PM),<http://www.thehindu.com/ entertainment/movies/censor-board-refuses-certificate-to-lady-orientedlipstick-under-my-burkha/article17353939.ece.> 
members had divergent views on a number of key issues and there was an urgent need to reconcile the incompatible and conflicting views. A good deal of behind-the-scenes discussions and negotiations were required to accommodate these divergent views. ${ }^{3}$ The constitutional structure is a good example of the principle of accommodation on matters of substance. It sought to preserve within it, the competing beliefs and values of various factions which tried to leave an imprint on the holy legal document. It is important to note how the Constitution framers were influenced by the great Isaiah Berlin's concepts of liberty and moral pluralism. His conviction that:

The old perennial belief in the possibility of realising ultimate harmony is a fallacy... that Great Goods can collide. But the collision, even if they cannot be avoided, can be softened. Claims can be balanced, compromises can be reached... Priorities, never final and absolute, must be established. ${ }^{4}$

As Bertrand Russell puts it, "liberation of creativeness ought to be the principle of reform both in politics and in economics." 5 To be consistent with this principle of reform, any useful political theory must seek to incorporate into it two important principles: First, the growth and vitality of individuals and communities is to be promoted as far as possible; second, the growth of one individual or community is to be as minimal as possible at the expense of another. According to Bertrand Russell, this principle of social reconstruction as applied impersonally in politics, is the principle of liberty. Thus liberty in itself, he says, is a negative principle. It tells us not to interfere. It condemns all avoidable interferences with freedom. Liberty, as the Constituent Assembly envisaged for our nation however, was based on Berlin's two concepts of liberty, positive liberty which would grant the individual a certain liberty to decide for himself/herself and negative liberty which would mean the absence of coercion or interference in the individual's

${ }^{3}$ Granville Austin, The Indian Constitution (2008).

${ }^{4}$ ISAIAH BERLIN,The Pursuit of the Ideal in The Crooked Timber of Humanity: Chapters in the History of Ideas (1990).

${ }^{5}$ Bertrand Russell, Principles 9: Social Reconstruction(1964). 
personal life, mainly by the government which is elected by exercising positive liberty. ${ }^{6}$

When Nehru first introduced the draft of the First Amendment in the Lok Sabha on 12 May, 19517, he didn't expect such reversal of events, where proponents for curbing free speech would take over the floor. Deeply concerned with the issue of freedom of speech, he oversaw the deliberations of the Cabinet Committee on the Amendment, and he surely did scrutinize the amending bill before approving its introduction in the Parliament. Then, as chairman of the Select Committee reviewing the bill, he recommended to his cabinet that the draft be altered to insert the cautionary word 'reasonable' to qualify the restrictions on the freedom of speech. ${ }^{8}$ However, he himself didn't like the word 'reasonable' as is evident in what he wrote to T.T. Krishnamachari stating that it would be an invitation for each case concerning the provision to go to the courts, instead of being solved at the legislative stage itself. ${ }^{9}$

On 29 May, 1951, the Congress Parliamentary Party approved the amending bill, having rejected 'in no uncertain terms' a move to drop the Select Committee's recommendation to include the word 'reasonable' as a protection of free expression. ${ }^{10}$ The First Amendment retroactively and prospectively empowered the government to impose 'reasonable restrictions' on the freedom of expression 'in the interests of the security of the State [replacing the words "tends to overthrow the State"], friendly relations with foreign States, public order, decency or morality, or in relation to contempt of court, defamation, or incitement to an offence'.11

\footnotetext{
${ }^{6}$ Isaiah Berlin, Four Essays On Liberty (2002).

7 Parliamentary Debates, Vol.12, Part 2, Cols. 8815-16 (1951).

${ }^{8}$ Granville Austin, Working a Democratic Constitution(1999).

91 Sarvepalli Gopal, Selected Works of Jawaharlal Nehru (Oxford University Press, 1985).

10 supra note 8 , at 49 .

11 INDIA CONST., amended by The Constitution (First Amendment) Act, 1951
} 


\section{Film Censorship in India}

The legendary director, Andrei Tarkovsky's films have contributed greatly to Indian cinema. However, they have remained in constant conflict with the Soviet Censor Board. It is surprising that his films are still able to make the profound effect because of his cinematography which is today called 'Tarkovskian', and for the profound philosophical questions that he poses, despite passing through heavy and senseless censorship. Soviet censors were unhappy with the excess of religious symbolism in 'Andrei Rublev' (1966), and as a result, the film was shortened by 25 minutes. Tarkovsky was not allowed to make a film for six years following its release. Screenings of 'The Mirror' (1975) and 'Stalker' (1979) were limited because of their complex language, and the press either gave them negative reviews or kept silent. 'Solaris' (1972) was more or less a successful film. Even though Soviet officials were irritated by its philosophical line and its arguments about God and cognition - and despite the fact that they demanded more than 40 changes to it - the film was still well known in the Soviet Union, probably because of its space exploration theme which really excited the Soviet Union back then during the heights of the Cold War. ${ }^{12}$

Andrei Smirnov, who directed 'Belarus Station' (1970), a cult Soviet film about veterans, remembers the process of working with censors. "There were no clearly formulated rules. Everything depended on the particular official who said yes or no," Smirnov said. "The Soviet State Committee for Cinematography [Goskino, which had to approve completed films] was just the final stage; censorship started on the first day of film production. At Mosfilm studios, local editors proofread the scripts, after which they were discussed by the arts council - a team of filmmakers, screenwriters and directors. And this wasn't done without the Party Committee,

12 Vida Johnson and Graham Petrie, The Films of Andrei Tarkovsky: A Visual Fugue (Indiana University Press, 1994). 
the local body of the Communist Party. And of course, they closely observed the films during filming." 13

As an Indian, one cannot avoid the clear and frightening similarities between stories of Soviet and Indian filmmakers. What is worse, is that, the Soviet Union has long collapsed and we've been a democracy for a good seventy years and concepts of 'freedom of speech and expression' and 'liberty' are not new or alien to us, as has been discussed before in this paper. Just as archaic and draconian laws can be traced back to our colonial roots, film certification too is no different. The British established the Central Board of Film Certification in the infancy of Indian cinema in 1918 and "perceived threats to the reputation of white women as well as any allusion to self-governance, the Indian nationalist movement, or Indian independence were heavily censored by the colonial authorities."14 In independent India, film censorship was established by the Cinematograph Act, $1952^{15}$ which came into force on 21 $1^{\text {st }}$ March, 1952. Section 5B of the Act, vested the power of pre-release censorship in a Board of Censors (now known as the Central Board of Film Certification [hereinafter CBFC]), a nonjudicial administrative body. It reads as follows:

1) A film shall not be certified for public exhibition if, in the opinion of the authority competent to grant the certificate, the film or any part of it is against the interests of 19 [the sovereignty and integrity of India] the security of the State, friendly relations with foreign States, public order, decency or morality, or involves defamation or contempt of court or is likely to incite the commission of any offence.

2) Subject to the provisions contained in sub-section (1), the Central Government may issue such directions as it may think fit setting

13 Ekaterina Sivkova, Artists under pressure: Soviet Filmmakers and Censorship Russia Beyond The Headlines (Moscow)(October 19, 2014),<https:/ /www.rbth.com/arts/2014/10/19/artists_under_pressure_ soviet_filmmakers_and_censorship_40723.html.>

14 W. MazZarella, Making Sense of Cinema in Late Colonial India, in Censorship in South Asia: Cultural Regulation from Sedition to Seduction(Indiana University Press, 2009).

15 The Indian Cinematograph Act, No. 37, Acts of Parliament, 1952. 
out the principles which shall guide the authority competent to grant certificates under this Act in sanctioning films for public exhibition. 16

The 'directions issued by the government' that sub-clause (2) talks about were extraordinarily broad, informing the Board that "no picture shall be certified for public exhibition which will lower the moral standards of those who see it...standards of life ....shall not be so portrayed as to deprave the morality of the audience... the prevailing laws shall not be so ridiculed as to create sympathy for violation of such laws."17

This gave the CBFC a carte blanche to ban or disapprove of whatever it deemed as immoral or unfit for public viewing. With such great subjectivity as 'vice and morality', 'relations between sexes', 'indecorous and sensuous postures', there is no room for doubt that the toughest stage for a film must obviously be getting clearance from the Censor Board.

This is what Gautam Bhatia describes in his new book 'Offend, Shock or Disturb' as the 'system of prior restraint'18- the "power to choke off the marketplace of ideas at its source."19 Further, one of the guidelines directs the Board to ensure that "dual meaning words that obviously cater to baser instincts are not allowed" $20-a$ guideline which gives a very strong leverage to the Censor Board in deciding the filters for obscenity and lewdness in cinema. To invoke rationality, the legislator must first confine the wide possibilities of irrationality. In order to understand freedom of expression in relation to art in India, mainly films, two foundational cases must be discussed.

\footnotetext{
${ }^{16} \S 5 B$, TheIndian Cinematograph Act, No. 37, Acts of Parliament, 1952.

17 K.A Abbas v. Union of India, A.I.R. 1971 S.C. 481.

18 Gautam Bhatia, Offend, Shock or Disturb: Free Speech Under Indian Constitution(2016).

${ }^{19} \mathrm{Id}$.

20 The Principles for Guidance in Certifying Films <http:// mib.nic.in/ acts/cinematograph-act-1952-and-rules.>
} 


\section{The Obscenity Test laid down by the Supreme Court}

Ranjit Udeshi $v$. State of Maharashtra ${ }^{21}$ was one of the first landmark cases concerning obscenity in art and understanding freedom of speech regarding the same. The facts are regarding a book that has never failed to garner wrong attention, a book that is classified as 'pornographic literature'- D.H. Lawrence's Lady Chatterley's Lover. Copies of the book which were banned were found with certain booksellers. They were prosecuted under section 292 of the Indian Penal Code which criminalizes the sale and possession of obscene books. The petitioners challenged the judgement on two grounds: first, that S. 292 of the Indian Penal Code (hereinafter referred to as IPC) was unconstitutional since it violated Article 19(1)(a); and secondly, in any event, Lady Chatterley's Lover was not an obscene book, within the meaning of the provision.

Back in the late 1950s, in the United States of America, Allen Ginsberg's classic poem Howl was on trial for obscenity charges. Judge Horn reserved two weeks to decide the verdict of the trial, during which he read Ulysses and the court decisions regarding it, as well as other materials of legal relevance. ${ }^{22}$ In his decision, he emphasized the importance of the freedoms of speech and press, stating that they "are inherent in a nation of free people" and "must be protected if we are to remain free, both individually and as a nation." 23 Additionally, he addressed a question that had resurfaced throughout the trial: could a work of literature be considered obscene based on certain words, if it possessed a redeeming literary value as a whole? Judge Horn maintained that it was not so. The distaste that a group of people hold for disagreeable words does not constitute obscenity. Personal dislike of certain words does not mean that they are not used within other social communities, or that they do not represent a separate

21 A.I.R.1965 S.C.881.

${ }^{22}$ 'Letters to the Editor'San Francisco Chronicle (April 1957) in Bill Morgan and Nancy J

Peters, Howl on Trial: The Battle for Free Expression (City Lights Books, 2006).

${ }^{23} \mathrm{Id}$. 
culture. This argument was congruent with the decision marked in the Roth $v$. United States case ${ }^{24}$, (which Judge Horn cited) wherein it was determined that a work could not be declared obscene, unless it lacked social importance. It was a big win for the Beat poets, especially for poets and artists around the world.

In India, two great authors, Ismat Chughtai and Sadat Hasan Manto also stood trial for obscenity under Section 292 of the IPC, which will be examined in the later paragraphs. The only crime they both claimed to have committed was questioning social regulations and revealing a human being's most basic instincts through a form of art, with great frankness and candour, which the society couldn't bear and nor could the judiciary. Bhatia, in his book, mentions this case as being indicative of 'obscenity as a weapon of cultural regulation'.25 However, both escaped punishment because 'obscenity' as an act had not been defined under Section 292 of IPC back then, and also because the prosecution failed to prove the Hicklin test as to whether the content might actually deprave and corrupt minds that are open to such immoral influences. ${ }^{26}$ In Ranjit Udeshi v. State of Maharashtra27, addressing the petitioner's first contention, the Court upheld the constitutional validity of Section 292. The grand jurist, Justice Hidayatullah noted that Article 19(2):

...makes an exception in favour of existing laws which impose restrictions on the exercise of the right in the interests of public decency or morality. Section 292 doesn't go beyond obscenity which falls directly within the words 'public decency and morality' of the second clause of the article. Obscenity denotes the quality of being obscene which means offensive to modesty or decency; lewd, filthy and repulsive. It

\footnotetext{
24 Roth v. United States, [1957] 354 U.S. 476.

${ }^{25}$ Bhatia, supra note $17,106$.

${ }^{26}$ R v. Hicklin, [1868] L.R. 2 Q.B. 360.

27 A.I.R.1965 S.C.881.
} 
cannot be denied that it is an important interest of the society to suppress obscenity. ${ }^{28}$

In the next paragraph, he noted:

Speaking in terms of the Constitution it can hardly be claimed that obscenity which is offensive to modesty or decency is within the constitutional protection given to free speech or expression, because the article dealing with the right itself excludes it. That cherished right on which our democracy rests is meant for the expression of free opinions to change political or social conditions or for the advancement of human knowledge. This freedom is subject to reasonable restrictions which may be thought necessary in the interest of the general public and one such is the interest of public decency and morality. Section 292 of Indian Penal Code, manifestly embodies such a restriction because the law against obscenity, of course, correctly understood and applied, seeks no more than to promote public decency and morality. ${ }^{29}$

What is baffling however is Justice Hidayatullah's conflicting opinion regarding 'obscenity'. He argues that while obscenity is protected under Article 19(1)(a), the decency and morality clause permits restricting obscene expression. However, in another part, he argues that the purpose of free speech and expression is to change political/social conditions or advance human knowledge, and consequently, obscenity is unprotected under Article 19(1)(a) itself, or in his words, "the article dealing with the right itself excludes it." 30

When the court had to take up the job of defining 'obscenity' as in Section 292 of IPC, but failed to do so, it revisited the Hicklin test, which the prosecutor in the case of Manto-Chugtai trials had failed to establish. The Court declared that "obscenity without a

28 RanjitUdeshi v. State of Maharashtra, A.I.R.1965 S.C.881.

${ }^{29} \mathrm{Id}$.

${ }^{30}$ Bhatia, supra note 17 , at 108 . 
preponderating social purpose or profit cannot have the constitutional protection of free speech." 31 The Court however upheld the 'restriction clause' of the Hicklin test which sought to 'protect not those who can protect themselves but those whose prurient minds take delights and secret sexual pleasure from erotic writings. ${ }^{132}$ The Court failed to understand how D.H Lawrence might actually be making a point about the human unconsciousness and what message the book might have for the ordinary reader. This is evident from the judgement's last few paragraphs:

The promptings of the unconscious particularly in the region of sex is suggested as the message in the book. But it is not easy for the ordinary reader to find it. The Machine Age and its impact on social life, which is secondary theme, does not interest the reader for whose protection, as we said, the law has been framed. 33

One might conclude from this judgement that the court might have, with good intentions, tried to interpret art in regard to the ordinary reader, who constitutes the major fraction of our society. However, this was a blow to art in India and sought to enforce morality on the dissenters and the 'social deviants' rather than enforce rule of law on the miscreants.

\section{Censorship in India}

In spite of not being able to recover from poverty since independence, Indian leaders and officials have made several attempts in the past to stop films depicting abject poverty in India. The most famous example for this would be Satyajit Ray's Pather Panchali (1955), which is now considered a classic in world cinemaa film which won the debutant director, the Best Human Document Award at the 1956 Cannes Film Festival. Thanks to Jawaharlal Nehru's personal admiration for the film and his appreciation of its

\footnotetext{
${ }^{31}$ Bhatia, supra note26.

32 Id.

33 Id.
} 
cinematic and humane qualities, the film could make it to Cannes. Nehru took the task upon himself, by overriding the opposition of government officials, to ensure that Pather Panchali would represent India, at Cannes. ${ }^{34}$ Other reactions were however, mostly philistine and unfounded, because it depicted social realities. For many years after its release, the trilogy's (Pather Panchali, Aparajito, Apur Sansar) unanticipated fame outside India, disturbed prosperous Indians especially those working in the commercial film industry of Bombay - because of its unsentimental portrayal of poverty. In 1981, the same official objection to the film was raised in Parliament, by Nargis, one of the biggest box-office stars of her time, who played the role of the rustic heroine in the 1957 blockbuster Mother India. She accused Ray of distorting India's image abroad - first in a parliamentary debate, then in an interview that she had given for an Indian magazine, in which she said: 'What I want is that if Mr. Ray projects Indian poverty abroad, he should also show "modern India". 35

A group of respected Indian filmmakers and writers responded by stating that:

The Modern India you speak of is the India of dams, of scientists, steel plants and agricultural reforms. Do you honestly believe that it is this India that is portrayed in the so-called commercial films of Bombay? In fact, the world of commercial Hindi films is peopled by thugs, smugglers, dacoits, voyeurs, murderers, cabaret dancers, sexual perverts, degenerates, delinquents and rapists, which can hardly be called representative of Modern India. ${ }^{36}$

34 Andrew Robinson, Satyajit Ray: The Inner Eye: The Biography of a Master Film-Maker (University of California Press, 1989).

35 Andrew Robinson, The Apu Trilogy EIndia, Himal Southasian (Kathmandu)(Dec. 19, 2010), <http:// old.himalmag.com/ component/ content/article/3456-the-apu-trilogy-and-india.html.> ${ }^{36} \mathrm{Id}$. 
A good example for the legal world would be the case of K.A. Abbas v. Union of India ${ }^{37}$, the case of the documentary film A Tale of Four Cities (1968) which, like Ray's Pather Panchali depicted poverty and inequality in the cities of Delhi, Bombay, Calcutta and Madras. The Board refused to grant the film a ' $U$ ' certificate, a decision affirmed on appeal to the Central Government, on the ground that it 'depicted immoral trafficking of women and soliciting, prostitution or procuration'. K.A. Abbas challenged the Government's decision, but by the time the case came up before the Supreme Court, the government had agreed to grant it a U certificate without the cuts. Consequently, he amended his petition to directly challenge the constitutional validity of the Cinematograph Act,1952 and the directions that the government must issue under it. ${ }^{38}$ The Court in this case, primarily, didn't accept the distinction between prior restraint and restraint in general and considered both to be governed by the standards of reasonable restrictions within Article 19(2) of the Indian Constitution. Secondly, following from the first, the word 'reasonable' in the Cinematograph Act was considered inconclusive in this regard. The Court referred to the guardianship role of the Courts as the legal protector of citizens in preserving public interest. ${ }^{39}$

\subsection{Prior Restraint}

Bhatia lays down his thoughts on a 'regime of prior restraint' as follows:

A regime of complete [emphasis added] prior restraint makes the problem far worse because it ensures that certain ideas can never even enter the marketplace. For post-publication punishment, the material in question has at least been placed before the public, and has entered the public sphere. Prior restraint allows the government immense powers of

\footnotetext{
37 K.A. Abbas v. Union of India, A.I.R. 1971 S.C. 481.

38 Bhatia, supra note 17 , at177.

39 Abbas v. Union of India, GLOBAL FREEDOM OF EXPRESSION COLUMBIA UNIVERSITY(blog), < https://globalfreedomofexpression.columbia.edu/ cases/abbas-v-india/>
} 
controlling the public sphere by determining what the public will have access [emphasis added] to in the first place. 40

Prior restraint, as has been mentioned previously in this paper, was an instrument of the British, and its applicability today makes not only a case of illogical succession of government suppression, but also the reflection of the nostalgic feelings of the colonized for its colonisers. The Supreme Court however, held that:

pre-censorship is but an aspect of censorship and bears the same relationship in quality to the material as censorship after the motion picture has had a run. The only difference is one of the stage at which the State interposes its regulation between the individual and his freedom. Beyond this there is no vital difference. ${ }^{41}$

This was despite a prior precedent of the Delhi High Court decision in the Brij Bhushan case ${ }^{42}$, which had prudently followed the American courts in holding prior restraint, unconstitutional. The Court also made the grand presumption of the universal recognition 'that the treatment of motion pictures must be different from that of other forms of art and expression...the instant appeal of the motion picture, its versatility, realism (often surrealism), and its coordination of the visual and aural senses...the motion picture is able to stir up emotions more deeply than any other product...'43 Upon a closer look at the judgment, one is reminded of the French film critic Andre Bazin's notion of 'objective reality'44 or even the legendary Swedish filmmaker Ingmar Bergman's thoughts on cinema, when he says "Film has dream, film has music. No form of

\footnotetext{
40 Bhatia, supra note 17 , at 178.

41 supra note 35.

42 BrijBhushan v. State of Delhi, 1950 S.C.R. 605.

43 supra note 35.

441 Andre Bazin, What is Cinema,(University of California Press, 2004).
} 
art goes beyond ordinary consciousness as film does, straight to our emotions, deep into the twilight room of the soul." 45

The conclusion of the Supreme Court was unfounded, as it didn't cite and most probably didn't look into film theory before making such a grand declaration. Surrealism for example, is still a category unexplored by Indian filmmakers and the Supreme Court still presumes its hovering existence in India cinema. This case can be, however, called as absurd, because in deciding a case on individual moral regulation, the court failed to make any point on the autonomy of the individual and individual freedom and the liberty of the individual under a state, as in the line of thought of Isaiah Berlin, who was so frequently cited when the Constituent Assembly first debated upon liberty and freedom. The court talked about the 'interests of the society' thereby invoking the Ranjit Udeshi case ${ }^{46}$ and how it came before the concept of individual morality as "it caters for the mass audience who are generally not selective about what they watch, the movie cannot be equated with other modes of communication." 47 It justified its stance on prior restraint, by stating that "cinema cannot be allowed to function in a free market place just as does the newspapers or magazines. Censorship by prior restraint is, therefore, not only desirable but also necessary." 48

The flaws can be seen in the court's general approach to moral philosophy in matters related to cinema. A movie can never offend people, it can at the most, affect certain people or certain sections of the society, and it is then that the question of censorship might be brought into the court. Cinema as an art form may be intimidating, as it is meant to invoke thoughts, stir up the viewer's consciousness, fears and desires, through moving images, placed not necessarily in order, but meandering like the endless rain or the constant sunshine. The primary objective of any art form is to make the viewer sacrifice his/her ego and question oneself.

${ }^{45}$ Ingmar Bergman, The Magic Lantern: An Autobiography (University of Chicago Press, 2007).

${ }^{46}$ supra note26.

${ }^{47}$ S. Rangarajan v. P Jagjivan Ram, (1989) 2 S.C.C. 574.

${ }^{48} \mathrm{Id}$. 
In the Ranjit Udeshi case, the court took upon itself the task of protecting those sections of the society that were ironically most vulnerable to corrupt and negative influences. In the Baragur Ramachandrappa case ${ }^{49}$, the Court focused on those communities that were most likely to be hurt by the offending text. The case concerned the 1995 Karnataka Sahitya Academy award winning novel Dharmakaarna which had allegedly offended the sentiments and feelings of the Veershaivas and the followers of Basaveshwara, a $12^{\text {th }}$ century saint. Similarly, the Rangarajan case narrowed down its observations on free speech and its calibration to the constituency that it felt would be most vulnerable in case of exposition.50 The Court went on to cite an academic study according to which "continual exposure to films of a similar character" would significantly affect the attitude of an individual or a group. On this basis, it deemed pre-censorship necessary. ${ }^{51}$ The Court interestingly suggested that making factually false claims is a ground for censorship which echoes the idea that the goal of free speech is to discover the truth. What is problematic with this judgement, is its narrow approach to art, as the Court declared

The motion pictures were originally considered as a form of amusement to be allowed to titillate but not to arouse. They were treated as mere entertainment and not an art or a means of expression. Movie motivates thought and action and assures a high degree of attention and retention. It makes its impact simultaneously arousing the visual and aural senses. The movie had unique capacity to disturb and arouse feelings. It has as much potential for evil as it was for good. It has an equal potential to instil or cultivate violent or good behaviour.

49 Sri BaragurRamachandrappa v. State of Karnataka, (2007) 3 S.C.C. 11.

50 supra note 44.

51 Gautam Bhatia, Free Speech and Public Order - II: Film Censorship and the Rangarajan Case, Indian Constitutional Law \& Philosophy, (Aug.09, 2013, 7:22 AM), <https://indconlawphil.wordpress.com/2013/08/09/freespeech-and-public-order-ii-film-censorship-and-the-rangarajan-case/> 
This was an archaic view of art and essentially how the doctrine of prior restraint had perpetuated itself.

\section{Judiciary and the Censor Board}

The film Bandit Queen (1994), with its explicit scenes of rape and sexual violence, also drew the Censor Board's 'prudish eyes' and was denied certification. Rejecting a challenge to the screening of the film, the Court held, in the case of Bobby International v. Om Pal Singh Hoon ${ }^{52}$ that "the object of the scenes was not to titillate the cinema goer's lust but to arouse in him sympathy for the victim and disgust for the perpetrators." 53 The Court, finding the scenes to be 'essential to the film' allowed its screening with an 'A' certificate. Hence, according to the Supreme Court's jurisprudence on obscenity, if it is used to provide a 'social message' for the general good, then it can be permitted to be portrayed in a film. Indian film-goers and citizens are hence denied their right to autonomy and individual freedom, have movies shoved down their throat, are told what to watch and why to watch a certain movie. The vesting of the wide authority in the government to decide what forms of expression people can or cannot be trusted with having exposure to, is why the Censor Board today can be so irrationally brutal in its functioning.

In the Rangarajan case, the grant of U-certificate to a film about caste-based reservations was revoked by the Madras High Court. The revocation was thereafter challenged by the Supreme Court, which surprisingly, for perhaps the first time, delivered a scathing counter-argument to the State's contention of 'disturbing public order'. It held that:

our commitment to freedom of expression demands that it cannot be suppressed unless the situations created by allowing the freedom are pressing and the community interest is endangered...The expression of thought should intrinsically dangerous to the public interests. In other words, the

\footnotetext{
52 Bobby International v. Om Pal Singh Hoon, (1996) 4 S.C.C. 1. ${ }^{53} \mathrm{Id}$.
} 
expression should be inseparably locked up with the action contemplated like the equivalent of a spark in a powder keg. ${ }^{54}$

The Court essentially ruled that a movie could be considered to be dangerous to the public interests only if it 'shouted fire in a crowded theatre. ${ }^{15}$ This is a commendable judgement from the Supreme Court because it recognised the 'effects of cinema' and how the viewer must pause and reflect after watching a movie. It sought to make a differentiation between such movies and movies which inherently might spark a fire. This is to not let the citizens from shying away from talking about cultural, political and social issues that affect their everyday lives but to exercise their freedom of speech and expression for its true value - to express dissent.

Father, Son \& Holy War (1994), a brave documentary on sexual violence and communalism in India, was given an 'A' Certificate. However, Doordarshan refused to telecast it. In the court, on behalf of Doordarshan, it was argued that the film had a high potential to spark of communal riots, as it would be viewed by 'illiterate and average persons who would be largely affected by its screening. ${ }^{156}$ This was a classic illustration of the colonial treatment of Indian citizens as 'subjects', which had continued from the previous cases of K.A. Abbas and Rangarajan. However, the Court came to the rescue of the documentary and rejected this contention, holding the standard to be that of the 'reasonable person', with an 'average, healthy and common sense point of view'. The Court also concluded that the documentary was neither obscene nor a threat to public order and it directed Doordarshan to screen it.

\footnotetext{
54 supra note 44.

55 Brandenburg v. Ohio [1969] 395 U.S. 444.

${ }^{56}$ DG, Directorate-General of Doordarshan v. AnandPatwardhan, (2006) 8 S.C.C. 433.
} 


\section{Censor Board and Moral Purity}

In consonance with Justice Hidayatullah's 'cherished right of the freedom of speech to advance human knowledge', the Court held in the Rangarajan case that 'moral values in particular, shouldn't be allowed to be sacrificed in the guise of social change or cultural assimilation.' The Court invoked a homogenous Indian identity by relying on Indian concepts like 'dharma' which it felt to be the 'bedrock of Indian civilization'. Dissenting opinion was refused by invoking the 'public morality' argument. However, it must be understood that India is not solely based upon the principle of Dharma, as can be observed from the Indian Constitution. The Court also tried to analyse the film's alleged depiction of Dr. Ambedkar as anti-egalitarian. After analysing certain scenes, it concluded that there was no such depiction, although at the same time, it shrewdly added that if such a depiction did exist, it would have to be subject to censorship, as Ambedkar cannot be thought of being anti-egalitarian. This again reflects India's ill-habit of canonization of its freedom fighters and putting them beyond historical questioning. If free speech is really to allow different views to be expressed by proponents and opponents alike, shouldn't it also extend to questioning the historical viewpoint that Dr. Ambedkar was a proponent of equality?

By the Court's reasoning in the Doordarshan case, it is clear that films like Lipstick Under My Burkha (2017) or When Harry Met Sejal (2017) are way beyond the firing line, as they hardly make a case for incitement of violence or lustful thoughts in the minds of the excitable crowd. Lipstick Under My Burkha, for example, is a film on women's sexuality and Indian feminism. The film obviously didn't deserve the wrath of the Censor Board, but a careful reflection and introspection after viewing. The Censor Board's refusal to grant it a clearance certificate implies its sexist mentality and functioning, which has found solace in the parallel legal provisions which make such censorship possible in the first place. A film scholar recently noted, drawing inspiration from the post-colonial theorist Partha Chatterjee:

Film censorship in India exemplified the distinction and tension between citizen and population that it is 


a characteristic feature of contemporary
democracy... thought the discourse of democracy is
predicated on the figure of the citizen and its
corollaries of autonomy, equal rights, and self-
representation, the modernizing agendas of post-
colonial nation-states like India presume
'populations' which are the objects of the
government, rather than citizens. ${ }^{57}$

\section{Conclusion}

The concepts of liberty and individual freedom that were discussed in the beginning of this paper were framed by the makers of our Constitution, after serious deliberations and discussions. If not for those debates, one cannot say for sure how worse the situation of censorship and freedom of speech and expression would have been, in our country today, keeping in mind that the film industry already finds itself in a dark forest of censorship and red-tapism. Let us work on a democratic presumption that our government does in fact constitute a part of the society. Having said that, to draw from J.S. Mill's concept of liberty, society can exercise power over any individual only to prevent harm to others, never for the good of those individuals themselves. ${ }^{58}$

In this paper, the researcher has argued that the doctrine of prior restraint dates back to colonial times and that it was primarily used for suppressing freedom of speech and expression. This doctrine was taken forward by the legislature and complied with, by the judiciary. The 'obscenity test' has always taken a conservative side, enforcing maximum curtailment of freedom of speech and expression and ever since the Ranjit Udeshi era, has given more leverage to the Censor Board and the judiciary to carry on with the same. This however, hasn't always been for the bad, as it ensured

57 T. Ganti, The Limits of Decency and the Decency of Limits, in Censorship in South Asia: Cultural Regulations from Sedition to Seduction(Indiana University Press, 2009).

58 Roger Crisp, Routledge Philosophy Guidebook to Mill on Utilitarianism(Psychology Press, 1997). 
that the complex and diverse social cohesion of the Indian society does not wither away.

However, in contrast to the above statement, the paper has also focussed on how the Censor Board's carte blanche with regard to deciding issues of morality is very dangerous and that this emanates from previous Supreme Court rulings, starting from Ranjit Udeshi to the Rangarajan case and other such important cases. To change the status quo, what is required is that such rulings must be discouraged and the judiciary must play a bigger role in curbing prior restraint, when it sees prospects for affecting certain societal issues positively, most currently, for example, the women's empowerment issue in India.

The Supreme Court has very often restricted itself to the understanding of censorship in regard to the upkeep of 'public morality', and in a display of superiority complex, interpreted the standards of the test of the 'reasonable man' (in multiple cases discussed in this paper). The Doordarshan case however let some ray of light seep in, by holding that not everything that is fiery onscreen need be harmful or might be of the potential to corrupt people. A lot of legal healing can be achieved by respecting art or art forms, which the current Censor Board seems to lack. By appointing someone so bigoted like Pahlaj Nihalani, the government sends out a strong message regarding its approach to cinema, or rather its indifference to it. Censoring certain words like 'intercourse' or movies because they depict Indian women as not mere housewives cooking for their husbands and children, as the Censor Board might want them to be, only goes on to present a mockery of the Censor Board itself. Such conduct is reminiscent of the Soviet censor board or censor boards in dictatorial countries. If the government probably makes an attempt to understand why art exists in the first place, perhaps it would revise its approach towards it. To quote Tarkovsky:

Some sort of pressure must exist; the artist exists because the world is not perfect. Art would be useless if the world were perfect, as man wouldn't 
look for harmony but would simply live in it. Art is born out of an ill-designed world. ${ }^{59}$

Filmmakers have the responsibility to expose lies and tell the truth, through the medium that is cinema, question social norms and dissent whenever the need arises. Censorship must be used wisely, for, it must not try to suppress deviating or dissenting voices, but only voices that reek of malice and ill-will, as there is a very clear distinction between the two. The Doctrine of Prior Restraint by all means, is being misused by the Censor Board, as it doesn't allow people to judge and reflect upon a cinema's value. By killing an unborn in the womb, it attempts to make social or cultural issues non-existent. Morality too, like power, if over-centralised, may lead to a nation full of obliging subjects and not argumentative citizens. That, for sure, is not what democracy is about.

\footnotetext{
59 'Andrei Tarkovsky Answers the Essential Questions: What is Art \&amp; the Meaning of Life?' Open Culture (21 June 2016) <http://www.openculture.com/2016/06/andrei-tarkovsky- answers-theessential-questions- what-is-art-the- meaning-of- life.html.>
} 